\author{
M. Suś-Ryszkowska, H. Matysiak, M. Miśkiewicz, E. Skołek, T. Wierzchoń, \\ K. J. Kurzydłowski \\ Warsaw University of Technology, Faculty of Materials Science and Engineering, \\ Warsaw
}

\title{
STRUCTURE AND PROPERTIES OF THE GLOW DISCHARGE NITRIDED LAYERS PRODUCED ON AUSTENITIC STEEL
}

\begin{abstract}
The study is concerned with the nitrided layers produced on 'medical' steel of the $316 \mathrm{~L}$ $(00 \mathrm{H} 17 \mathrm{~N} 14 \mathrm{M} 2)$ grade at a temperature of $450^{\circ} \mathrm{C}$. The results of the microstructural observations performed by TEM and of the phase analysis of the layers are presented and discussed. The examinations were conducted in the regions extending from the surface down to a depth of about $25 \mathrm{um}$. The nearsurface zone appeared to contain nitrogen austenite and fine precipitates. There were also certain phases in the lamellar form. Because of the applicative aspect of the glow discharge nitriding of 316 steel, the examinations also included its mechanical strength, in particular the static tensile strength and the lowcycle fatigue strength. The static tensile tests showed no significant differences in the yield stress between the samples in the starting state and those subjected to the low-temperature glow discharge assisted nitriding. The low-cycle fatigue tests (which, in view of the differences between the properties of the untreated material and the nitrided layers, can be classified among the most severe mechanical tests) either, indicated no essential differences in the fatigue properties of the samples subjected to the surface treatments conducted under various conditions.
\end{abstract}

Key words: nitriding, austenitic steel, glow discharge, ,transmission electron microscopy, fatigue tests

\section{EXAMINATION METHODS}

Samples made of 316 steel $(0.019 \% \mathrm{C}, 0.327 \% \mathrm{Si}, 1.377 \% \mathrm{Mn}, 17.206 \% \mathrm{Cr}$, $10.602 \% \mathrm{Ni}, 2.052 \% \mathrm{Mo}, 0.004 \% \mathrm{Ti}, 0.0431 \% \mathrm{~N}, 0.313 \% \mathrm{Cu}, 0.085 \% \mathrm{Co}, 0.026 \% \mathrm{P}$, $0.0264 \% \mathrm{~S}$ ) were subjected to nitriding under glow discharge conditions at a temperature of $450^{\circ} \mathrm{C}$ for 4 hours (process 1 ), $5 \mathrm{~h}$ (process 2 ), and $6 \mathrm{~h}$ (process 3 ), and, at an elevated frequency of $80 \mathrm{kHz}$, for $6 \mathrm{~h}$ (process 4 ) in a $\mathrm{N} 2+\mathrm{H} 2$ atmosphere (1:1 ratio).

The microstructure was observed in a Hitachi S-3500N scanning electron microscope. The metallographic cross-sections were etched using the Adler reagent of the composition: $3 \mathrm{~g} \mathrm{CuCl}_{2}-2 \mathrm{NH}_{4} \mathrm{Cl}-2 \mathrm{H}_{2} \mathrm{O}, 50 \mathrm{~cm}^{3} \mathrm{HCl}, 15 \mathrm{~cm}^{3} \mathrm{FeCl}_{3}, 20 \mathrm{~cm}^{3} \mathrm{H}_{2} \mathrm{O}$. The microstructure was also examined in a JEOL transmission electron microscope at an accelerating voltage of $120 \mathrm{kV}$. The TEM samples were prepared so as to enable observation from the surface down into the material. Fig.1 schematically shows the cross-sections of the layer at the TEM sample. The samples were thinned by ion polishing. This method revealed not only the microstructure formed during the nitriding, but also radiation-induced defects in the form of fine dislocations and dislocation loops. 
The chemical composition on the cross-sections of the samples was determined using the EDS method. The microhardness (HV0.05) was measured with a Zwick Materialprufung 322212002 micro-hardnessmeter, the surface roughness - with a Taylor Hobson Form Talysurf scanning profilometer, series 2, and the phase composition - with a Brucker D8 Discover X-ray diffractometer using $\mathrm{CuK}_{\mathrm{a}}$ radiation. The static tensile test was conducted at temperatures of $23^{\circ} \mathrm{C}$ and $600^{\circ} \mathrm{C}$ using an INSTRON 1115 strength machine equipped with auxiliary equipment. A schematic diagram of the test samples is shown in Fig. 2. The starting straining rate was $4 \times 10^{-} 4 \mathrm{~s}^{-1}$ in all the samples. The stress-strain curves obtained were used for determining the basic strength indices:

- yield strength- Re,

- tensile strength - $\mathrm{R}_{\mathrm{m}}$, and

- total elongation - $\mathrm{A}_{\mathrm{c}}$.

The low-cycle fatigue test was performed on 6 axisymmetric samples, in accord with the Polish Standard PN-84/H-04334-2 (Fig.3, 2-initial state, 4-after the surface treatment), using an MTS 810 strength machine with a nominal maximum force of $100 \mathrm{kN}$. The test was conducted within the $\pm 50 \mathrm{kN}$ range with the use of an extensometric force sensor. The samples were fixed stiffly in hydraulic holders. The criterion of failure was taken to be the force reduction to $60 \%$ of the maximum force exerted during the last sequence of the 50 cycles. Prior to the test, the hydraulic system was adjusted, over the $25 \%$ range, using $316 \mathrm{~L}$ steel samples with mechanical parameters similar to those of the samples examined.

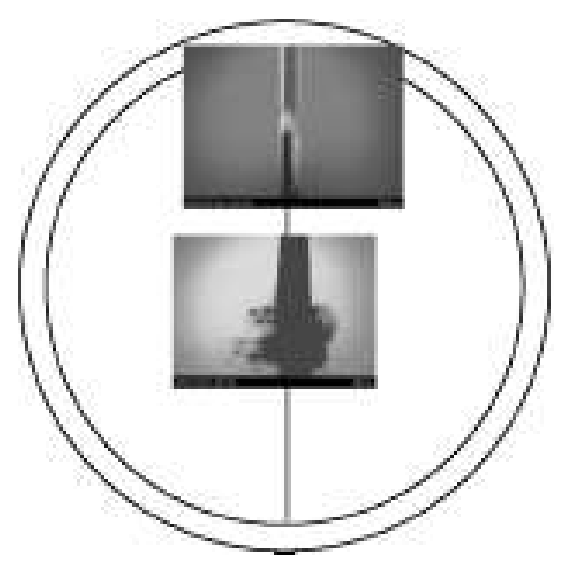

Fig. 1. Schematic representation of a TEM sample

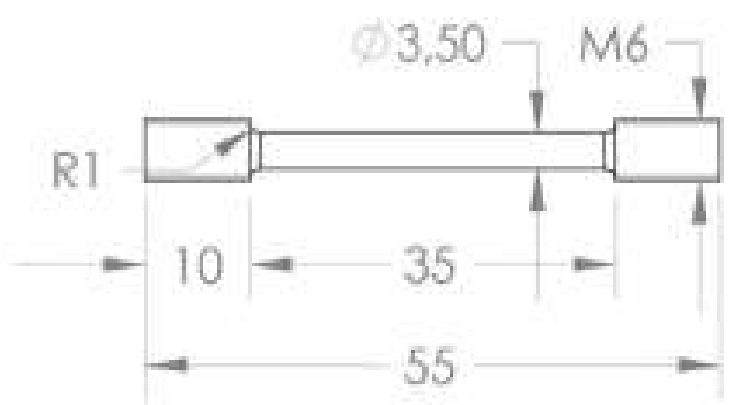

Fig. 2. Sample intended for static tensile test 


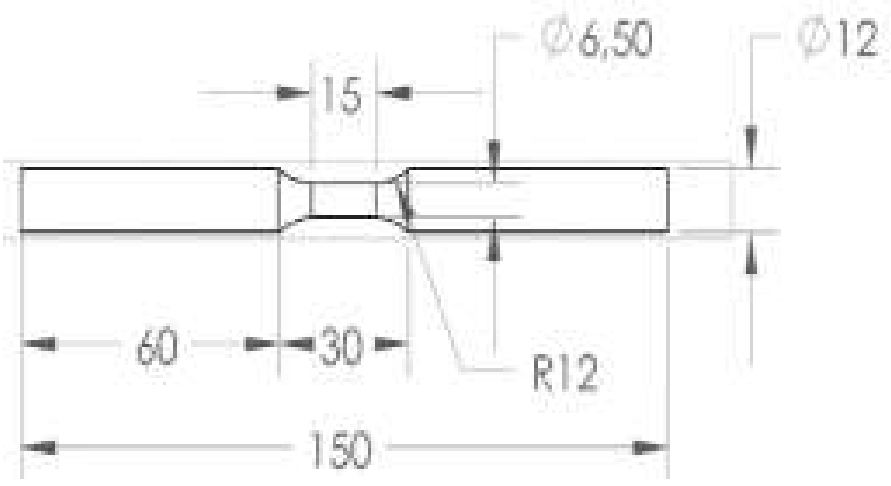

Fig. 3. Sample intendedfor low-cycle fatigue test

\section{RESULTS}

Fig. 4 shows the microstructure, surface appearance and element distribution in the nitrided layer produced on $316 \mathrm{~L}$ steel by glow discharge assisted nitriding at a temperature of $450^{\circ} \mathrm{C}$ for $5 \mathrm{~h}$. The layers thus obtained were about 5 um thick and had a surface hardness of $1200 \mathrm{HV} 0.05$. The nitrogen penetration depth was about $10 \mu \mathrm{m}$. Table 1 gives the values of the stereometric parameters that characterize the surface topography of the material in the starting state and after the glow discharge nitriding at a temperature of $450^{\circ} \mathrm{C}$.

a)

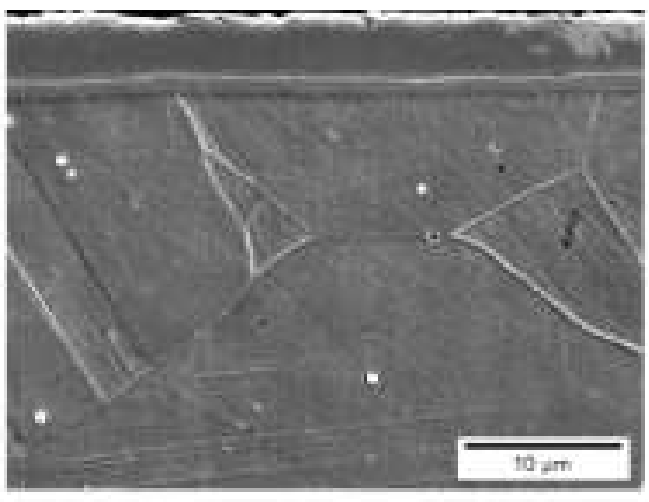

b)

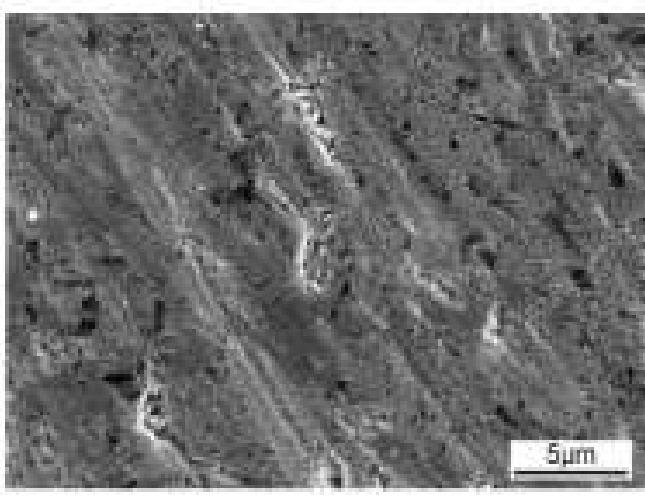




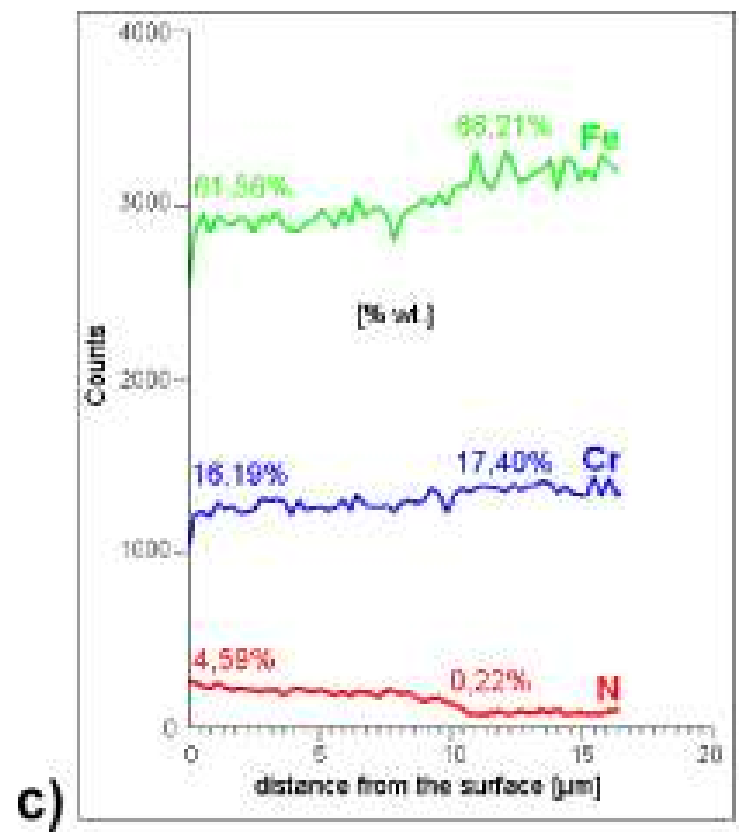

Fig. 4. (a) Microstructure of the layer produced on $316 \mathrm{~L}$ steel by glow discharge nitriding at a temperature of $450^{\circ} \mathrm{C}$; (b) the appearance of the surface and (c) distributions of chromium and nitrogen within the layer as a function of the distance down from the surface (process 2)

Table 1. Stereometric parameters characterizing the surface topography of $316 \mathrm{~L}$ steel in the starting state and after the glow discharge assisted nitriding at a temperature of $450^{\circ} \mathrm{C}$

\begin{tabular}{|c|c|c|}
\hline Parameter & Initial state $[\mu \mathrm{m}]$ & $\begin{array}{c}\text { Nitrided } 450^{\circ} \mathrm{C} \\
{[\mu \mathrm{m}]}\end{array}$ \\
\hline $\mathrm{Ra}$ & 0.0591 & 0.0939 \\
\hline $\mathrm{R}_{\mathrm{q}}$ & 0.077 & 0.12 \\
\hline $\mathrm{R}_{\mathrm{p}}$ & 0.965 & 0.546 \\
\hline $\mathrm{R}_{\mathrm{V}}$ & 0.53 & 0.907 \\
\hline $\mathrm{Rt}$ & 1.5 & 1.45 \\
\hline $\mathrm{R}_{\mathrm{z}}$ & 1.12 & 1.28 \\
\hline
\end{tabular}

$\mathrm{R}_{\mathrm{a}}$ - mean arithmetic deviation of the roughness profile, $\mathrm{R}_{\mathrm{q}}$ - mean square deviation of the roughness profile, $R_{p}$ - maximum height of the roughness profile hill, $R_{v}$ maximum depth of the roughness profile valley, $R_{t}$ - maximum height of the roughness peak $\left(R_{t}=R_{p}+R_{v}\right), R_{z}$ - mean difference between the 5 highest peaks and the 5 deepest valleys of the roughness profile (acc. To ISO 4287/1-1984)

The phase analysis of the layer identified expanded austenite (the so-called phase $\mathrm{S}$ ) present in the entire volume of the layer and a thin layer $(\leq 0,5 \mu \mathrm{m})$ of iron nitride and chromium nitride $\mathrm{CrN}$ on its surface (Fig.5).

Since it is known from the literature that the thickness of the nitrided layer ranges from about 5 to about $30 \mu \mathrm{m}[1,2]$ and, depending on the process parameters even to $70 \mu \mathrm{m}$ $[3,4]$, we conducted our TEM observations at various depths of the sample. Representative photographs of the nitrided layer are shown in Fig.6. 


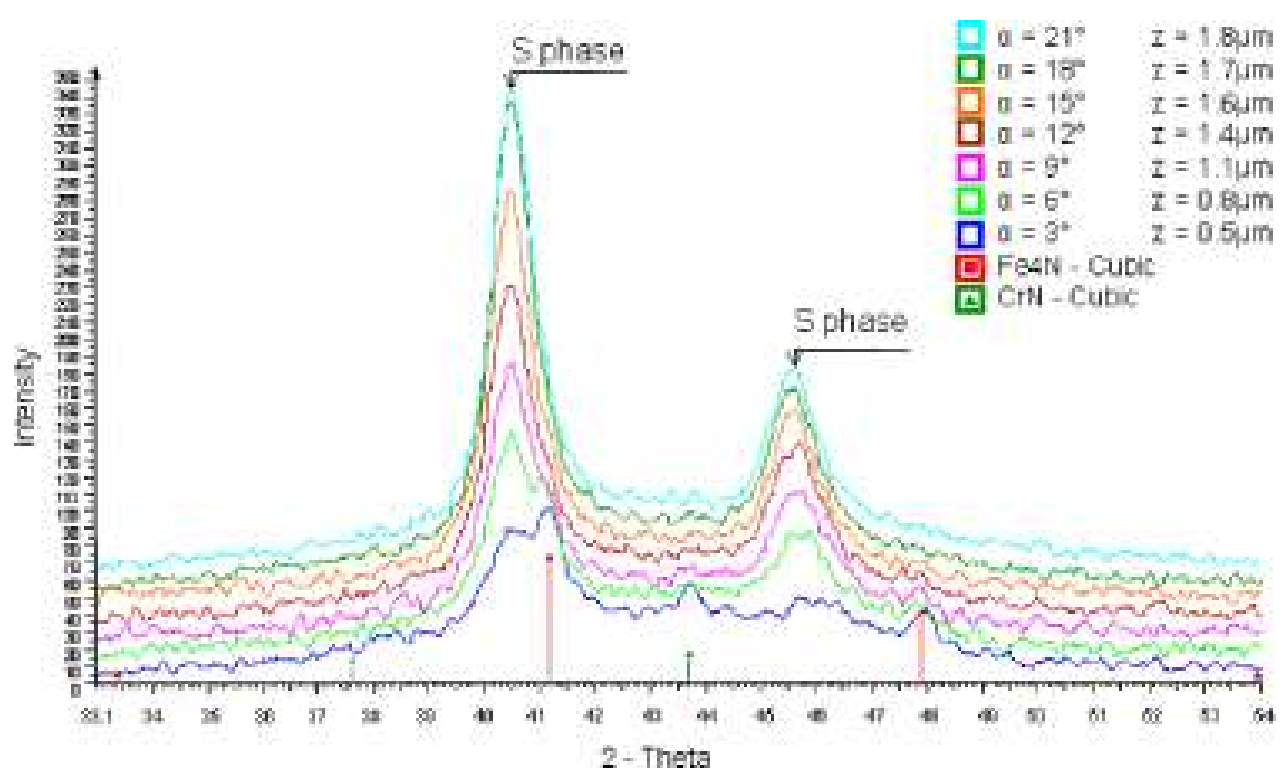

Fig. 5. Diffraction pattern of the surface of 316L steel after glow discharge nitriding (process 2)
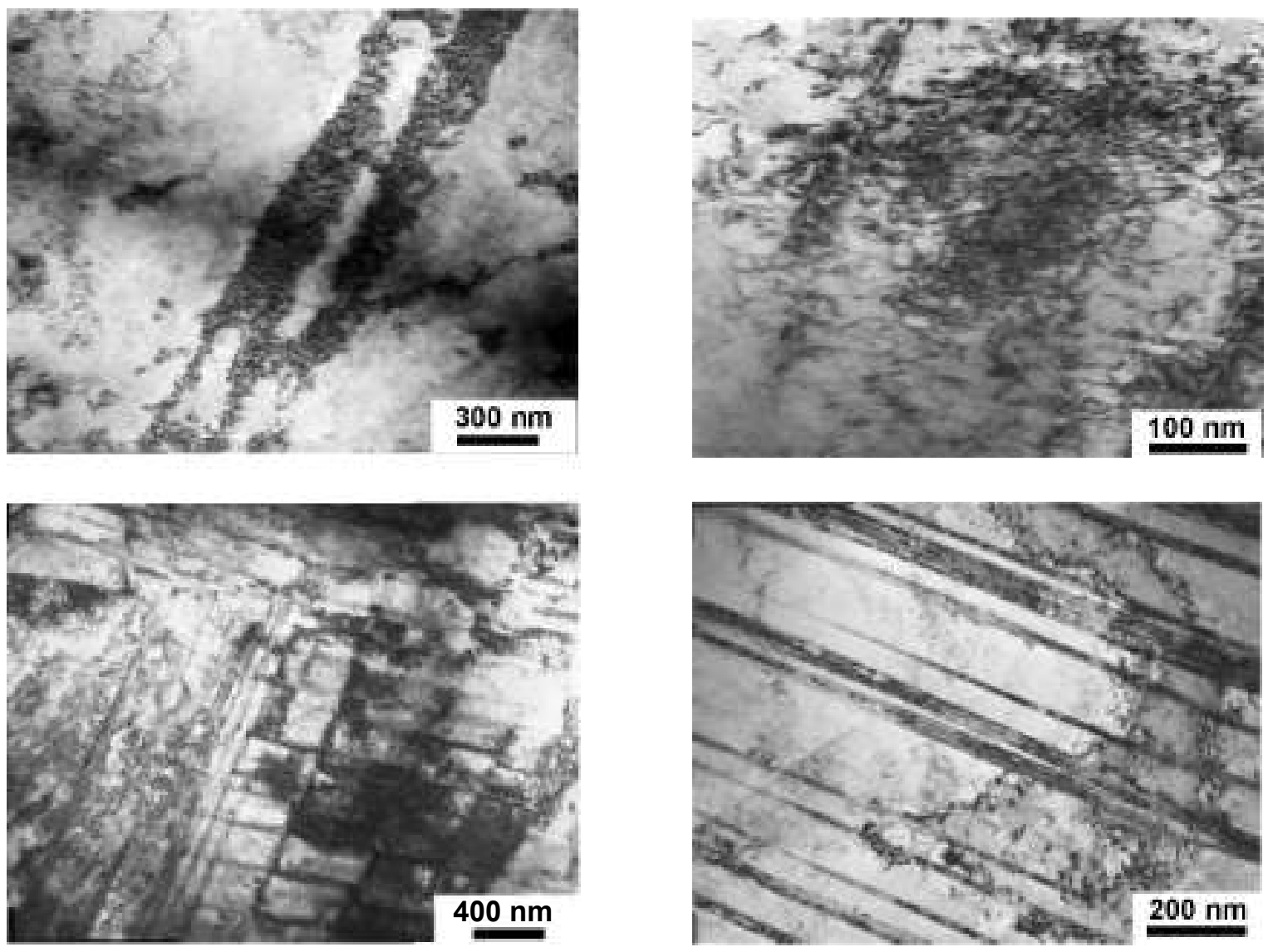

Fig. 6. Microstructure of $316 \mathrm{~L}$ steel after the glow discharge assisted nitriding

TEM observations show dislocations of high density, especially near the sample surface, i.e. in the nitrided layer. We can infer from our TEM observations, and analyses of the phase composition (and the reported literature data $[1,3]$ ) that the near surface layer contains expanded austenite and, from place to place, $\mathrm{CrN}$ precipitates. It is worth noting that the fact that the expanded austenite is a solution super-saturated interstitially by nitrogen greatly affects the structural and diffraction images since such a solution is 
liable to lattice distortion and low phase stability. Hence the tendency to form $\mathrm{CrN}$ precipitates, especially in the regions far away from the layer surface. Frequently, these two phases occur in a lamellar form (bands 10 to $50 \mathrm{~nm}$ wide) with even smaller precipitates present within the bands. Similar band shaped structures have been observed by other investigators $[1,3,7,8,11]$. Some of the authors suggest that these bands are associated with the stacking faults and dislocations [9] formed as a result of the super-saturation with nitrogen that take place during nitriding. The nitriding process promotes the formation of the band structures, which most probably are initiated by the numerous stacking faults present in the nitrogen saturated austenite of the YN type. According to the literature reports [e.g. 10], the band-shaped structures are characteristic features of expanded austenite, just as are the regions of high dislocation density with the dark spots of precipitates which can be identified as $\mathrm{CrN}$. Micrographs of the microstructure, together with the diffraction patterns taken at a depth of about $8 \mu \mathrm{m}$ are shown in Fig.7.
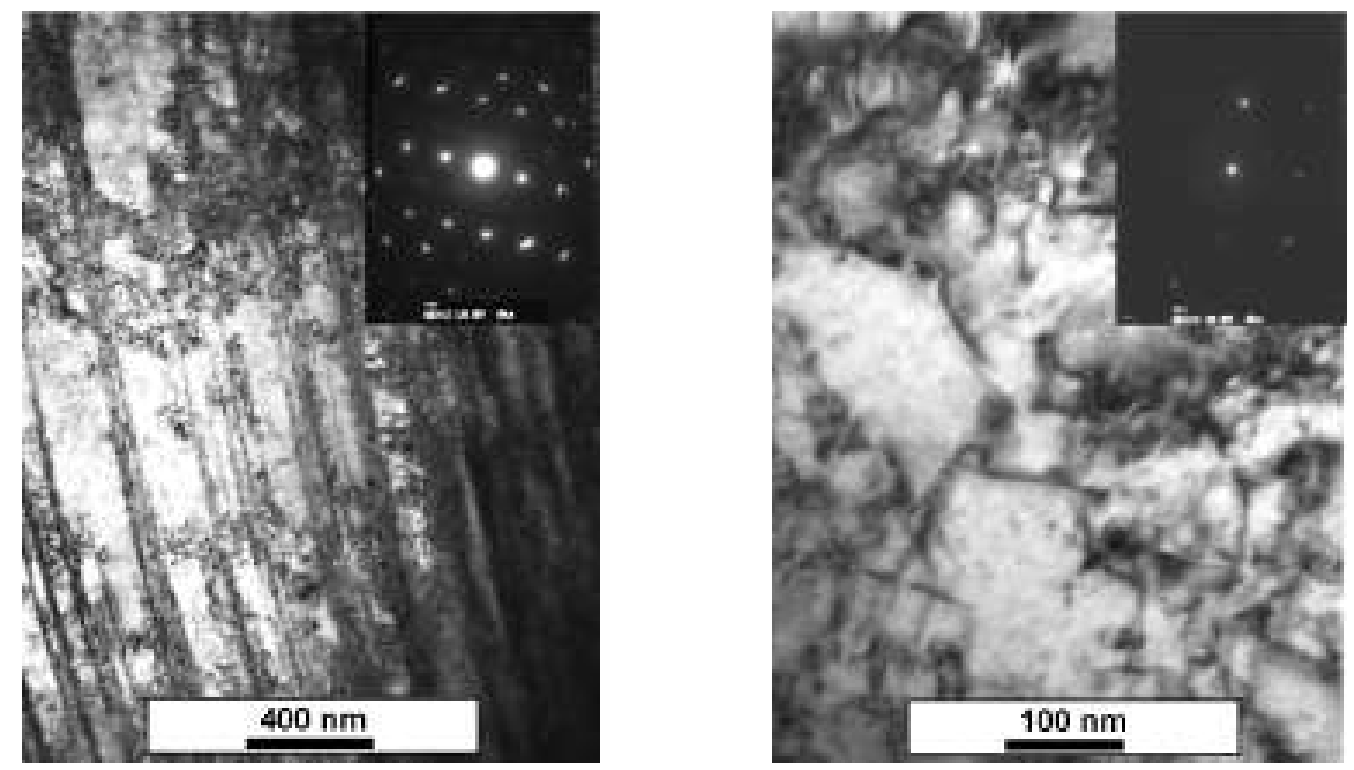

Fig. 7. Microstructure of nitrided 316L steel and respective diffraction images

\section{MECHANICAL EXAMINATIONS}

In order to find how the nitrided layers produced on 316L steel under various glow discharge conditions affect the mechanical properties of the steel, the steel thus nitrided was subjected to low-cycle fatigue tests and to mechanical examinations. The fatigue tests were conducted on axisymmetric samples under the conditions of elastic-plastic 
deformation at a constant cycle asymmetry coefficient $\mathrm{R}=-1\left(\mathrm{R}=\varepsilon_{\min } / \varepsilon_{\max }\right)$. For the sake of comparison, the material in the starting state was also subjected to the tests.

Our experiments were based on the assumption that the nitrided layers would improve the tribological properties of the steel with its corrosion resistance being preserved, which was expected to be achieved by increasing the hardness of the steel and reducing its ductility.

The discontinuities formed in the layer during the low-cycle straining may enhance the propagation of the principal crack and, finally, may lead to rapid failure of the product stability. Moreover, in the so-called transition regions, there exists a stress gradient which results from the difference in the expansion coefficients between the materials of the layer and the core. To obviate this drawback and increase the fatigue strength, we should tend to induce compressive stresses in the layer so that they hamper the nucleation and propagation of cracks by closing the crack tips.

Our results show that the nitrided layers do not degrade the fatigue properties of 316L steel, and even slightly improve them depending on the thickness of the expanded austenite layer. Taking into account the stochastic character of the fatigue processes, and hence a possible spread of the results obtained, we may state that the nitrided layers and the untreated material withstand a similar number of the loading cycles until failure (Table 2).

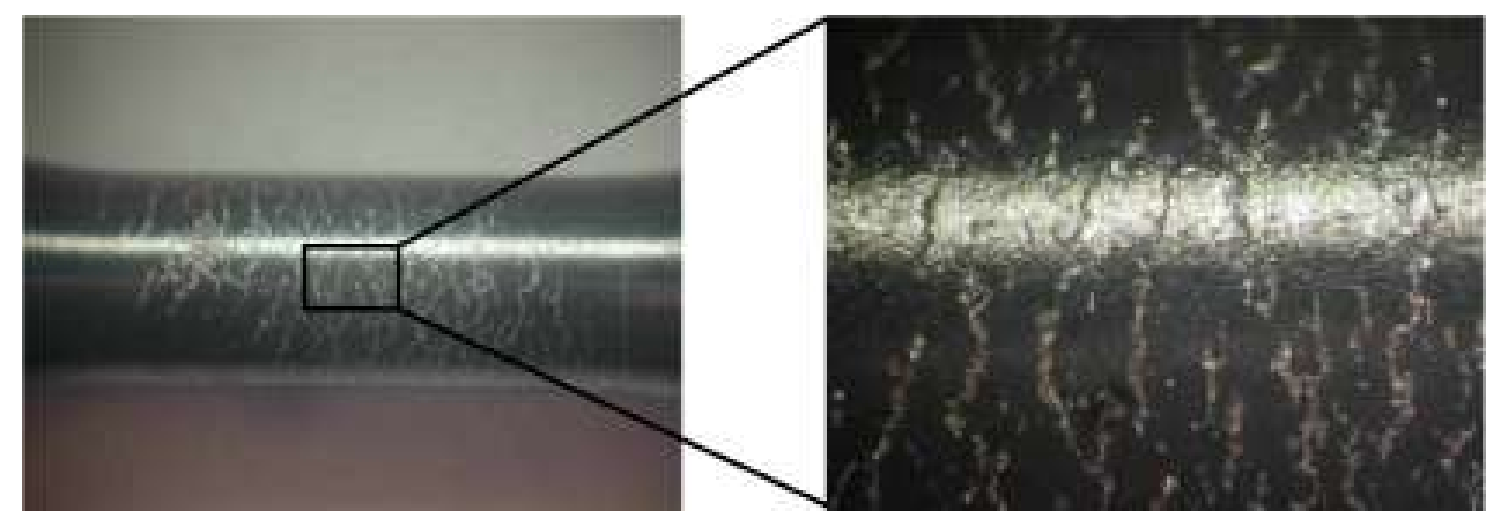

Fig. 8. Appearance of a nitrided layer on $316 \mathrm{~L}$ steel after a low-cycle fatigue test (process 3 )

During the cyclic deformation process, a crack network was observed to form on the surfaces of all the layers examined. An example of such macro-cracks is shown in Fig.8. These cracks did not however enhance the crack nucleation processes or the development of the critical cracks that would reduce drastically the fatigue strength. Observations of the layer surface revealed small mass losses. No delimination was however observed, which is evidence that the bond between the layer and the substrate was effective and could successfully withstand the cyclic loading.

As can be seen from Table 2, it is only the nitrogen austenite layer produced by nitriding at a frequency of $80 \mathrm{kHz}$ (process 4), whose fatigue strength is significantly reduced compared to that of the starting material. Radial cracks and mass losses appeared on its entire circumference as early as during the first loading cycles, leading to stress concentration and defect accumulation in this region and, in consequence, to the reduction of the fatigue strength. The number of cycles recorded until failure, Nf, was here reduced by a factor of 2 .

The static tensile test of this layer shows a decrease of the total elongation with respect to that measured in the other layers and in the starting material, with the values of the characteristic stresses $\mathrm{R} 0.2$ and $\mathrm{R}_{\mathrm{m}}$ being preserved. Fig.9 compares the tensile curves obtained at room temperature for $316 \mathrm{~L}$ steel in the starting state and the steel with the nitrided layers formed on its surface. Table 3 gives the basic strength parameters of these materials measured at room temperature and at a temperature of $600^{\circ} \mathrm{C}$. 
Table 2. Mechanical properties of the steel $316 \mathrm{~L}$ compared to the properties of the nitrided steel

\begin{tabular}{|c|c|c|c|c|}
\hline Sample & $\begin{array}{c}\text { Deformation } \\
\text { amplitude }\end{array}$ & $\begin{array}{c}\text { Minimum test } \\
\text { stress [MPa] }\end{array}$ & $\begin{array}{c}\text { Maximum test } \\
\text { stress [MPa] }\end{array}$ & $\begin{array}{c}\text { Number of } \\
\text { cycles until } \\
\text { failure } \mathrm{N}_{\mathrm{f}}\end{array}$ \\
\hline $\begin{array}{c}316 \mathrm{~L} \text { steel } \\
\text { initial state 2 }\end{array}$ & $2 \%( \pm 1 \%)$ & -418 & 447 & 927 \\
\hline $\begin{array}{c}316 \mathrm{~L} \text { steel - nitriding } \\
\text { (process 1) }\end{array}$ & $2 \%( \pm 1 \%)$ & -512 & 498.5 & 1191 \\
\hline $\begin{array}{c}316 \mathrm{~L} \text { steel - nitriding } \\
\text { (process 2) }\end{array}$ & $2 \%( \pm 1 \%)$ & -514 & 500.5 & 1087 \\
\hline $\begin{array}{c}316 \mathrm{~L} \text { steel - nitriding } \\
\text { (process 3) }\end{array}$ & $2 \%( \pm 1 \%)$ & -536 & 510 & 911 \\
\hline $\begin{array}{c}316 \mathrm{~L} \text { steel - nitriding } \\
\text { (process 4) }\end{array}$ & $2 \%( \pm 1 \%)$ & -633.404 & 520 & 475 \\
\hline
\end{tabular}
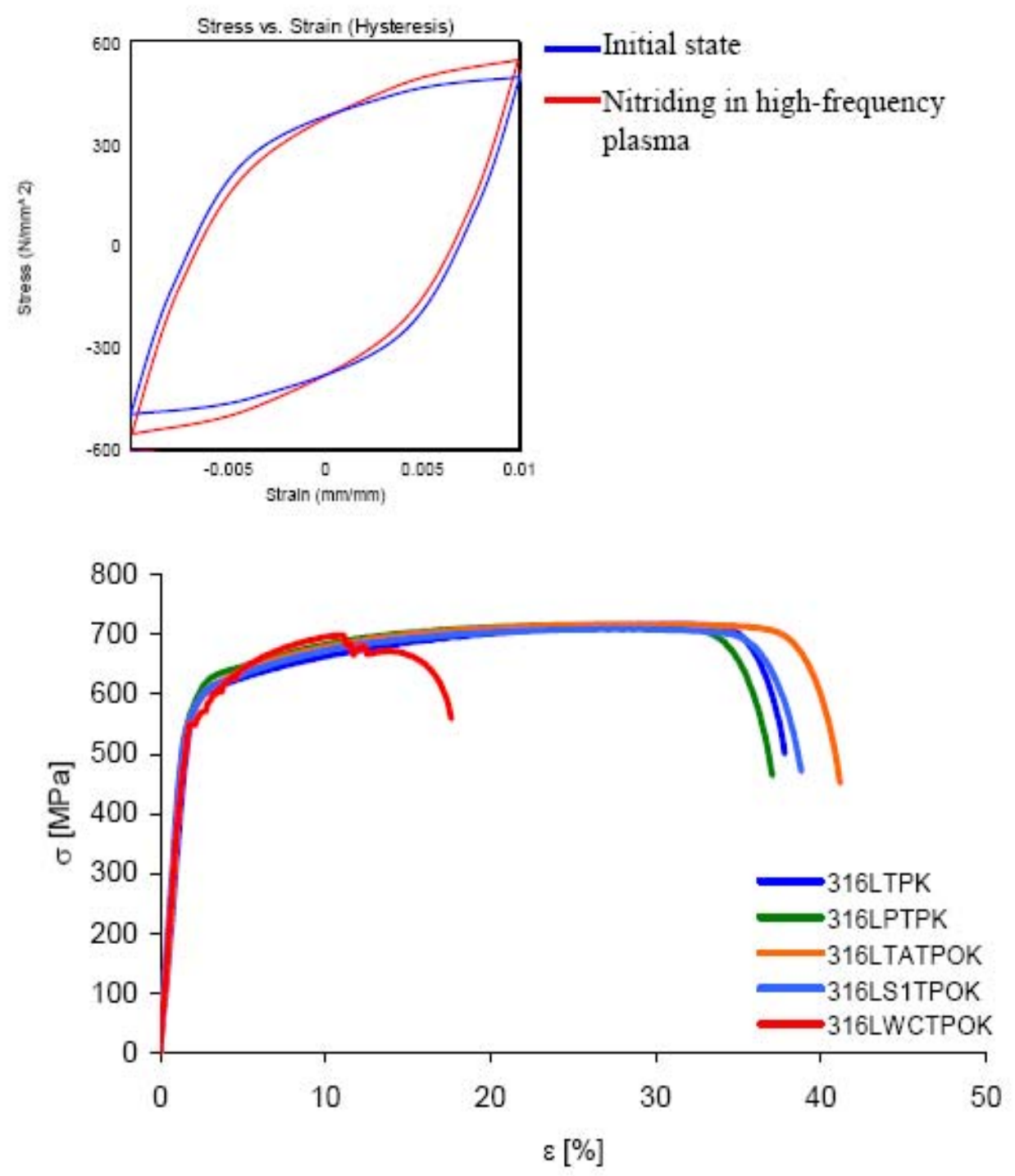

Fig. 9. Tensile curves obtained for $316 \mathrm{~L}$ steel in the starting state and after nitriding 
Based on the results of the static tensile test we can state that the strength parameters, in particular the yield stress, tensile strength and total elongation, of the samples in the starting state and those subjected to the surface treatment do not differ essentially. The only exception is the material treated in the high-frequency plasma, whose total elongation, measured at room temperature and at an elevated temperature, is smaller.

Table 3. Basic strength parameters of $316 \mathrm{~L}$ steel in the starting state and after nitriding, measured at room temperature and at $600^{\circ} \mathrm{C}$

\begin{tabular}{|c|c|c|c|}
\hline $\mathrm{T}\left[{ }^{\circ} \mathrm{C}\right]$ & $\begin{array}{l}\mathrm{R} 0,2[\mathrm{MPa}] \\
\text { Yield stress }\end{array}$ & $\begin{array}{c}\mathrm{R}_{\mathrm{m}}[\mathrm{MPa}] \text { Tensile } \\
\text { strength }\end{array}$ & $\begin{array}{c}\mathrm{A}_{\mathrm{c}}[\%] \text { Total } \\
\text { alongation }\end{array}$ \\
\hline \multicolumn{4}{|c|}{ 316L steel - initial state } \\
\hline 23 & 579 & 716 & 36.0 \\
\hline 600 & 369 & 448 & 17.8 \\
\hline \multicolumn{4}{|c|}{ 316L (process 1) } \\
\hline 23 & 559 & 720 & 35.7 \\
\hline 600 & 315 & 440 & 17.0 \\
\hline \multicolumn{4}{|c|}{ 316L - (process 2) } \\
\hline 23 & 560 & 711 & 38.8 \\
\hline 600 & 408 & 504 & 17.8 \\
\hline \multicolumn{4}{|c|}{ 316L - (process 3) } \\
\hline 23 & 548 & 717 & 39.8 \\
\hline 600 & 449 & 516 & 12.5 \\
\hline \multicolumn{4}{|c|}{$316 \mathrm{~L}-($ process 4$)$} \\
\hline 23 & 512 & 687 & 16.0 \\
\hline 600 & 345 & 466 & 10.5 \\
\hline
\end{tabular}

FINAL REMARKS

The glow discharge assisted nitriding of $316 \mathrm{~L}$ steel at a temperature of $450^{\circ} \mathrm{C}$ yielded nitrided layers $10-30 \mu \mathrm{m}$ thick with a surface hardness of about $1200 \mathrm{HV} 0.05$ (starting material - 230HV0.05).

The layers contained nitrogen austenite (known as the phase $\mathrm{S}$ ) in their entire volumes, and iron nitride $\mathrm{Fe} 4 \mathrm{~N}$ and chromium nitride $\mathrm{CrN}$ in the near-surface zones.

TEM observations confirmed the presence of expanded austenite $(\gamma \mathrm{N})$ and $\mathrm{CrN}$ precipitates in the layer microstructure. Other characteristic features of the layers are numerous stacking faults and high dislocation density. The sub-structure of the stacking faults is formed as a result of the saturation austenite with nitrogen, since this reduces the stacking fault energy [14].

Nitrided layers on steel $316 \mathrm{~L}$, formed at temperature $450^{\circ} \mathrm{C}$, do not degrade its mechanical properties of steel. These layers are increasing wear resistance of friction 
and slightly its corrosion resistance [2].

Process of glow discharge nitriding (frequency of $80 \mathrm{kHz}$ ) leads to decreasing of strength properties of steel $316 \mathrm{~L}$. It is caused by the fact, that the layer thickness to the level of about $30 \mu \mathrm{m}$.

\section{ACKNOWLEDGMENT}

The study was financed by project KBN nr 3T08C00127

\section{REFERENCES}

1. W.Liang, S.Juncai, X. Xiaolei „Low pressure plasma arc source ion nitriding compared with glow-discharge plasma nitriding of stainless steel", Surface and Coatings Technology 145 (2001) $31-37$.

2. J. R. Sobiecki, T. Borowski, H. Matysiak, K. J. Kurzydłowski, T. Wierzchoń, Increase of durability of stainless steel using the glow discharge treatment, Proc. of 2nd. Inter. Conf. Heat Treat. and Surf. Eng. in Automotive Applications, Riva del Garda, Italy 2005, CD-Rom.

3. E. Menthe, K.-T. Rie "Further investigation of the structure and properties of austenitic stainless steel after plasma nitriding", Surface and Coatings Technology 116 - 119 (1999) $1999-204$.

4. T. Czerwiec ,N. Renevier, H. Michel "Low - temperature plasma - assisted nitriding", Surface and Coatings Technology 131 (2000) 267 - 277.

5. S. Leigh, M. Samandi, G.A. Collins, K.T. Short, P. Martin, L. Wielunaki "The influence of ion energy on the nitriding behaviour of austenitic stainless steel" ,Surface and Coatings Technology 85 (1996) $37-43$.

6. J. Erneman ,M. Schwind, P. Liu, J. - O. Nilsson, H. - O.. Andrén, J.Ågren „Precipitation reactions caused by nitrogen uptake during service at high temperatures of a niobium stabilized austenitic stainless steel", Act Materialia 52 (2004) $4337-4350$.

7. W. Liang, X. Xiaolei , XTEM and XPS studies of plasma nitrocarburising layers on 0.45\% C steel", Surface and Coatings Technology 126 (2000) 288 - 293.

8. D.R.G. Mitchell, D.J. Attard, G.A. Collins, K.T. Short „Characterisation of PP and RF plasma nitrided austenitic stainless steels using plan and cross - sectional TEM techniques", Surface and Coatings Technology 165 (2003) $107-118$.

9. M.K. Lei, Z.L. Zhang „, Plasma source ion nitriding of pure iron : formation of an iron nitride layer and hardened diffusion layer at low temperature", Surface and Coatings Technology 91 (1997) $25-31$.

10. X.L. Xu, L. Wang, Z.W. Yu, Z.K. Hei ,, Microstructural characterization of plasma nitrided austenitic stainless steel", Surface and Coatings Technology 132 (2000) $270-274$.

11. X. Xiaolei, W. Liang, Y. Zhiwei ,H. Zukun „A comparative study on microstructure of the plasma - nitrided layers on austenitic stainless steel and pure Fe", Surface 
and Coatings Technology 192 (2005) $220-224$.

12. M.P. Fewell, D.R.G. Mitchell, J.M. Priest, K.T. Short, G.A.Collins „, The nature of expanded austenite", Surface and Coatings Technology 131 (2000) $300-306$.

13. J.P. Riviere, P. Meheust, J.P. Villain, C. Templier, M. Cahoreau, G. Abrasonis, L. Pranevicius „High current density nitrogen implantation of an austenitic stainless steel", Surface and Coatings Technology 158 - 159 (2002) 99 - 104.

14. Z.Q. Liu, D.X. Li, Z.K. Hei, H. Hashimoto "Electron diffraction study on superstructure in the compound layer of ion - nitrided pure iron", Scripta Materialia 46 (2002) 179 - 185.

15. T. Christiansen, M. A. J. Somers, On the crystallographic structure of S-phase, Scripta Materialia 50 (2004) 35-37. 